\title{
Setting conservation priorities for crop wild relatives in the Fertile Crescent
}

\author{
Wathek Zair $\mathbb{B} \cdot$ Nigel Maxted $\cdot$ Ahmed Amri
}

Received: 27 March 2017 / Accepted: 13 October 2017/Published online: 22 November 2017

(C) The Author(s) 2017. This article is an open access publication

\begin{abstract}
The aim of this paper is to contribute directly to the systematic, long-term conservation of crop wild relatives (CWR) in the Fertile Crescent by setting conservation priorities to secure and improve CWR conservation in situ and ex situ as a means of underpinning global food security. We established the first priority list of CWR within the Fertile Crescent following several criteria comprising production value $(\mathrm{m} \times \mathrm{p})$, projected production value $(\mathrm{m} \times \mathrm{p})$, production area (ha), projected production area (ha), native status, energy supply (kcal/capita/day), protein supply (g/capita/day), fat supply (g/capita/day), occurrence status, gene pool, taxon group, and threat status. An inventory of 220 priority CWR was established for the Fertile Crescent region. We followed twelve prioritisation approaches and assessed 21,080 species. About $4 \%$ of the total species (835 species) were identified as CWR that have socio-economic value for the region. These $835 \mathrm{CWR}$ species were prioritised to
\end{abstract}

Electronic supplementary material The online version of this article (doi:10.1007/s10722-017-0576-3) contains supplementary material, which is available to authorized users.

W. Zair $(\bowtie) \cdot$ N. Maxted

School of Biosciences, University of Birmingham,

Edgbaston, Birmingham B15 2TT, UK

e-mail: wathekzair@yahoo.com

\section{A. Amri}

Genetic Resources Section, International Centre for Agricultural Research, Dry Areas (ICARDA),

P.O. Box 6299, Rabat, Morocco create the CWR priority list which consisted of 220 species (1\% of the total species assessed). The majority of the CWR priority list (185 species) were related to cereal, vegetable, and industrial crops and 35 of them are related to fruits and trees. The CWR priority list includes crop wild relatives of the genera Aegilops (20 species), Lactuca (11 species), Avena (11 species), Carthamus (11 species), Allium (9 species), Thinopyrum (10 species), and Triticum ( 3 species). We present the first inventory of 220 priority CWR for the Fertile Crescent. The inventory helps to improve in situ and ex situ conservation and the genetic diversity of CWR. Both the inventory and the methodology applied in prioritisation can be used in setting national, regional, and global conservation strategies. The recommendations will help the Fertile Crescent meet its targets in conserving CWR diversity as well as making sure that CWR genetic resources are preserved to prevent and tackle global food insecurity.

Keywords Conservation - Prioritisation · Food security · Genetic diversity · Plant genetic resources

\section{Introduction}

Human population is increasing rapidly. It was estimated that the population will reach 11.2 billion by 2100 (UN 2017). That is why there is an urgent 
need to improve crop varieties so we could produce more food and crops will be able to improve yield, are resistant to insects and diseases, can tolerate abiotic stress such as high temperature and drought (Araus et al. 2008). Crop wild relatives are species of plants that are genetically close to cultivated crops. They are an important source of plant genetic materials that can be used for crop improvements. CWR have genes that made them adapted to various stresses in their natural environments (Maxted et al. 2006). A CWR should be in Gene pool one or Gene pool two for the gene transfer to be done easily (Maxted et al. 2006). CWRs have been used to improve crops resistant to diseases, for example in Australia, a crop wild relative of wheat has been used successfully as a source of a gene which is resistant to cereal cyst nematode. The gene from the CWR was transferred to bread wheat (Appels and Lagudah 1990). CWRs have also been used to improve varieties' resistant to stress, for example, Hordeum spontaneum $\mathrm{K}$. Koch and Triticum dicoccoides Körn. the CWRs of barley and wheat have genes that can make them tolerate salty soil and drought (Nevo and Chen 2010). Crop wild relatives are threatened in their natural habitat, this is due to urbanization, constructing roads, deforestation, desertification, intensive farming, and erosion of soil and plant genetic resources, pollution of land and water, scarcity of water, overgrazing and the impact of climate change (El-Beltagy 2006; Derneg 2010). Trigo et al. (2010) state that climate change impacted negatively on the vegetation in the Fertile Crescent (Trigo et al. 2010). For all the above-mentioned reasons, there is an urgent need to conserve CWR in the Fertile Crescent and conserve their natural habitats. There are several CWR taxa around the world and the number was estimated to be approximately 50,000-60,000 species worldwide and of these approximately 10,740 of them are a high priority for food security (Maxted and Kell 2009). In the Fertile Crescent region, there is a red list assessment that was done for plants in Jordan. Nearly $40 \%$ (1072 species) of the flora in Jordan was red list assessed. The assessment found 106 species of the total species have been listed as threatened nationally with 19 species of them being critically endangered, 54 species being endangered, 33 as vulnerable and one species (Salvia farinacea) as regionally extinct (Taifour and El-Ohlah 2014). Authors have used a number of approaches for CWR prioritisation (Maxted et al. 1997; Mitteau and Soupizet 2000; Barazani et al.
2008; Ford-Lloyd et al. 2008; Maxted and Kell 2009; Magos Brehm et al. 2010). Magos Brehm et al. (2010) used nine prioritisation criteria (native status, economic value, ethnobotanical value, global distribution, national distribution, ex situ conservation status, in situ conservation status, legalisation, and threat assessment) and applied them to the Portuguese CWR. Species were listed based on their priority from high to low and the top 50 were identified. Those CWR species that were found to be a high priority were give prioritisation for conservation in Portugal (Magos Brehm et al. 2010). While in the United States, Khoury et al. (2013) used crop production and food supply data from the Food and Agriculture Organisation of the United Nations statistical database (FAOSTAT) giving a US priority list consisting of 821 CWR taxa (Khoury et al. 2013). Fielder et al. (2015) applied five prioritisation criteria: use of the related crop, commercial importance of the associated crop, native status, relatedness degree of the CWR to the crop, and latest change in the population to prioritise $148 \mathrm{CWR}$ taxa (Fielder et al. 2015). Other authors when prioritising CWR taxa have used other combinations of prioritising criteria (Barazani et al. 2008), but related crop value, relative CWR relatedness (indicating potential ease of CWR use in breeding), and threat assessment have been used widely. The Fertile Crescent is a very important centre in the plant genetic resources field as it is a centre of crop domestication. Major crops such as wheat, barley, lentils and chickpeas were first domesticated in the Fertile Crescent thousand years ago, (Zeder 2011). The Fertile Crescent is located in Syria, Iraq, Israel, Palestine, Jordan, Lebanon and Turkey (Fig. 1).

The Fertile Crescent is in the Mediterranean basin region which is a major region that is known for its great plants' diversity. It has between 25,000 and 30,000 plant species (Heywood 2003). Vavilov, (1926) located Crop Origin centres in the world where crops originated and the Fertile Crescent contains two Vavilov centres (Vavilov 1926). Willcox (2012) stated that early farming started in Southwest Asia (the Fertile Crescent today). Willcox (2012) also specified that nine major crops were domesticated in this region including einkorn, emmer, barley, lentil, pea, chickpea, bitter vetch, broad bean, flax (Willcox 2012).

It was estimated that 390,900 vascular plants are known to human (Kew 2016). The number of vascular plants in Turkey is 9753 taxa (Guner et al. 2012). In 


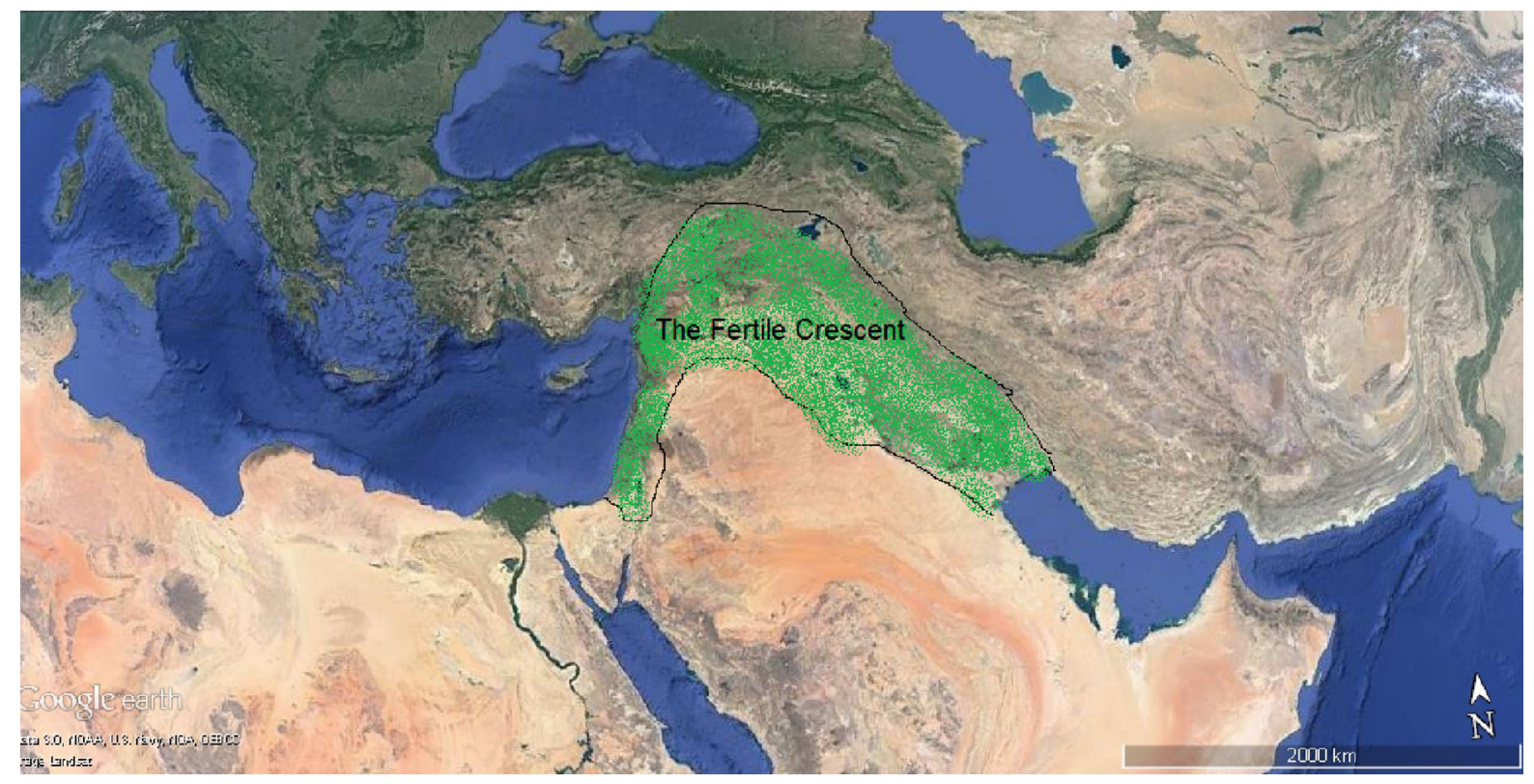

Fig. 1 A map showing the location of the Fertile Crescent

Syria, vascular plants amounted for 3500 plants (Post 1933). Zohary $(1966,1986)$ illustrates that the number of vascular plants in Israel and Palestine is 2700 taxa. Taifour and El-Oqlah (2017) recently updated the vascular plants list in Jordan and now it is 2600 taxa (Taifour and El-Oqlah 2017). Lebanon has 2606 vascular plants (Mouterde 1970). Iraq has 3220 vascular plants (Ghazanfar and McDaniel 2015). The number of vascular plants in the Fertile Crescent equals 21,080 species (Ghazanfar and McDaniel 2015). Vincent et al. (2013) states that the Fertile Crescent is one of the regions with the highest concentration of CWR per unit area globally. Lebanon, Israel, Greece, Portugal, Azerbaijan, Bulgaria, Syria, Italy, Spain, and Turkey are areas with the top CWR concentration per unit, four of them found in the Fertile Crescent (Lebanon, Israel, Syria, and Turkey) (Vincent et al. 2013). Castaneda-Alvarez et al. (2016) also emphasised that the Mediterranean is one of the richest regions in the world for CWR, with 84 global priority taxa in every $25 \mathrm{~km}^{2}$. Such findings confirm that the Fertile Crescent, as part of the Mediterranean basin, is a hotspot for crop diversity (Castaneda-Alvarez et al. 2016). The Fertile Crescent is possibly the most important centre for ensuring global food security, yet few studies that have been undertaken on CWR genetic erosion in the region
(Keisa et al. 2008) indicate that local CWR diversity is being rapidly eroded, and combined with the likely adverse impact of climate change, there is a need to apply contemporary genetic and GIS techniques as an aid to the development of a regional CWR conservation strategy for the Fertile Crescent and so help in safeguarding global food security. This paper addresses the creation of a CWR checklist, prioritisation, and the creation of a CWR inventory as a first step towards developing a CWR conservation and use strategy for the region.

\section{Methods}

To create the CWR Checklist, the PGR forum was used. It is an online database designed to facilitate CWR conservation and CWR use for Euro-Mediterranean countries. The catalogue was built with a set of available databases including Euro + Med PlantBase (http://www.euromed.org.uk/), Mansfeld's World Database of Agricultural and Horticultural Crops (Hanelt and IPK 2001; http://Mansfeld.ipkgatersleben.de/Mansfeld/), with forestry genera from the enumeration of cultivated forest plant species (Schultze-Motel 1966), and ornamental genera from the Community Plant Variety Office (http://cpvo. 
Table 1 Groups for the production value (in 1000 USD)

\begin{tabular}{llc}
\hline Group & Range (in 1000 USD) & Points \\
\hline G0 & Below 1 & 0 \\
G1 & $1-2554$ & 1 \\
G2 & $4765-27,146$ & 2 \\
G3 & $27,170-52,983$ & 3 \\
G4 & $54,696-103,121$ & 4 \\
G5 & $105,340-149,290$ & 5 \\
G6 & $164,134-235,667$ & 6 \\
G7 & $236,222-378,381$ & 7 \\
G8 & $392,493-668,148$ & 8 \\
G9 & $689,250-3,951,780$ & 9 \\
G10 & $4,903,859$ & 10 \\
\hline
\end{tabular}

europa.eu/en) and Schippmann et al. (2002) (Maxted et al. 2007). Cwrdiversity also was used, it is an online database for information on CWR (Vincent et al. 2012) (http://www.cwrdiversity.org). The regional plant checklist consists of a widely accessible working set of known plant species with accepted Latin names. The introduced plant species were excluded; but the near-endemic species were included in order to obtain a complete and comprehensive regional species checklist of the native species. The checklist went through thorough evaluation as there were lots of duplications and synonyms. Species names were checked thoroughly against many sources. Mansfeld, Zeven and de Wet (1982) were used to get a more comprehensive list. After checklist approval, prioritisation started. The regional plant checklist was prioritised following several criteria comprising production value $(\mathrm{m} \times \mathrm{p})$, projected production value $(\mathrm{m} \times \mathrm{p})$, production area (ha), projected production area (ha), native status, energy supply (kcal/cap$\mathrm{ita} /$ day), protein supply (g/capita/day), fat supply (g/capita/day), occurrence status, gene pool, taxon group, and threat status. The production value of crops was taken from FAOSTAT (2016) which is a database that shows production for 20 most important agricultural commodities for each country around the world. FAOSTAT (2016) database allow users to compare

Table 2 Selection criteria, groups, and point scale used for the prioritisation

\begin{tabular}{|c|c|c|c|c|c|c|c|c|c|c|c|}
\hline \multirow[t]{2}{*}{ Criteria/group } & \multicolumn{11}{|c|}{ Points } \\
\hline & 0 & 1 & 2 & 3 & 4 & 5 & 6 & 7 & 8 & 9 & 10 \\
\hline Production value $(\mathrm{M} \times \mathrm{P})^{*}$ & G0 & $\mathrm{G} 1 * *$ & G2 & G3 & G4 & G5 & G6 & G7 & G8 & G9 & G10 \\
\hline Projected production value $(\mathrm{M} \times \mathrm{P})^{*}$ & G0 & $\mathrm{G} 1 * *$ & G2 & G3 & G4 & G5 & G6 & G7 & G8 & G9 & G10 \\
\hline Production area (has)* & G0 & $\mathrm{G} 1 * *$ & G2 & G3 & G4 & G5 & G6 & G7 & G8 & G9 & G10 \\
\hline Projected production area (has)* & G0 & $\mathrm{G} 1 * *$ & G2 & G3 & G4 & G5 & G6 & G7 & G8 & G9 & G10 \\
\hline Native status* & & Non-nat & & & & & & & & & Nat \\
\hline Energy supply (kcal/capita/day)* & G0 & $\mathrm{G} 1 * *$ & G2 & G3 & G4 & G5 & G6 & G7 & G8 & G9 & G10 \\
\hline Protein supply (g/capita/day)* & G0 & G1 & & & $\mathrm{G} 2$ & & & & G3 & & \\
\hline Fat supply (g/capita/day)* & G0 & G1 & & & $\mathrm{G} 2$ & & & & G3 & & \\
\hline Occurrence status & Inv & & & & Int & & & & & & Nat \\
\hline Gene pool level & & GP3 & & & & GP2 & & & & & GP1 \\
\hline Taxon group level & & TG4 & & & TG3 & & & TG2 & & & TG1 \\
\hline Threat status IUCN & EW & & DD & $\mathrm{LC}$ & & NT & VU & & EN & & CR \\
\hline
\end{tabular}

* Values of the related crop; ** G0-G10: categories for the corresponding criterion values (Int \$1000) in 2011 values in 2014 values in 2014

Inv invasive, Int introduced, Nat native, $G P$ gene pool, $T G$ taxon group, $L C$ least concerned, $N T$ near threatened, $V U$ vulnerable, $E N$ endangered, $C R$ critically endangered 
production and yield for certain food crop for several countries. The economic value of crops in the Fertile Crescent has been taken from the CROP-FAOSTAT unit (http://faostat.fao.org/default.aspx?PageID= 567\#ancor). As shown in Table 1, points were allocated to CWR according to their production value (in 1000 USD).

The CWR species are ranked from closely related to more remote ones as follows: primary gene pool (GP1), secondary gene pool (GP2), and tertiary gene pool (GP3). The database was accessed to check the gene pools of CWR species that occur in the Fertile Crescent. The International Union for Conservation of Nature (IUCN) (http://www.iucnredlist.org/) has notable information aimed at assessing the risk of extinction to species. The IUCN Red List is designed and managed by the IUCN Global Species Programme and the Species Survival Commission (SSC). It is established upon specific criteria to assist in knowledge of the conservation status of species globally. Selection criteria, groups, and point scale used for the prioritisation are summarised in Table 2.

A simple ranking system (SRS) was used and each CWR was given a score accordingly. Each group is allocated a number of points based on the importance or implication of the level/status of the group. For example, invasive taxa get 0 point and native get points; introduced get 4 points. The number and range of the categories are from G0 to $\mathrm{G} 10$ and are determined according to the occurrence status. Ten groups were created and linked to the production value (from G0 to G10). G0 means the CWR has no commercial value at all and G10 has 10 points. The higher the production value of the crop, the more points it scores. Ten groups were established to represent the production value, (Table 2); each category gets a number of points. In this case the larger the production value, the more points the taxa get. Once the points were allocated to all the groups for each criteria, the next step was to apply these methods to each CWR species in the regional checklist and relate the matching points. The final points for a species is the total score of all the criteria listed. Species that got the highest score are the top priority; then the inventory was formed of the first 220 species on the list. The inventory was sent to ICARDA for approval as the ICARDA is one of the leading centers in conserving plant genetic diversity in the region. The species in the inventory were evaluated and confirmed that they represent the most important CWR in the region.

\section{Results}

The total number of taxa in the Fertile Crescent is 21,080 taxa and 835 taxa are CWR that are related to
Fig. 2 The organisation of the taxa in the CWR checklist and the CWR inventory

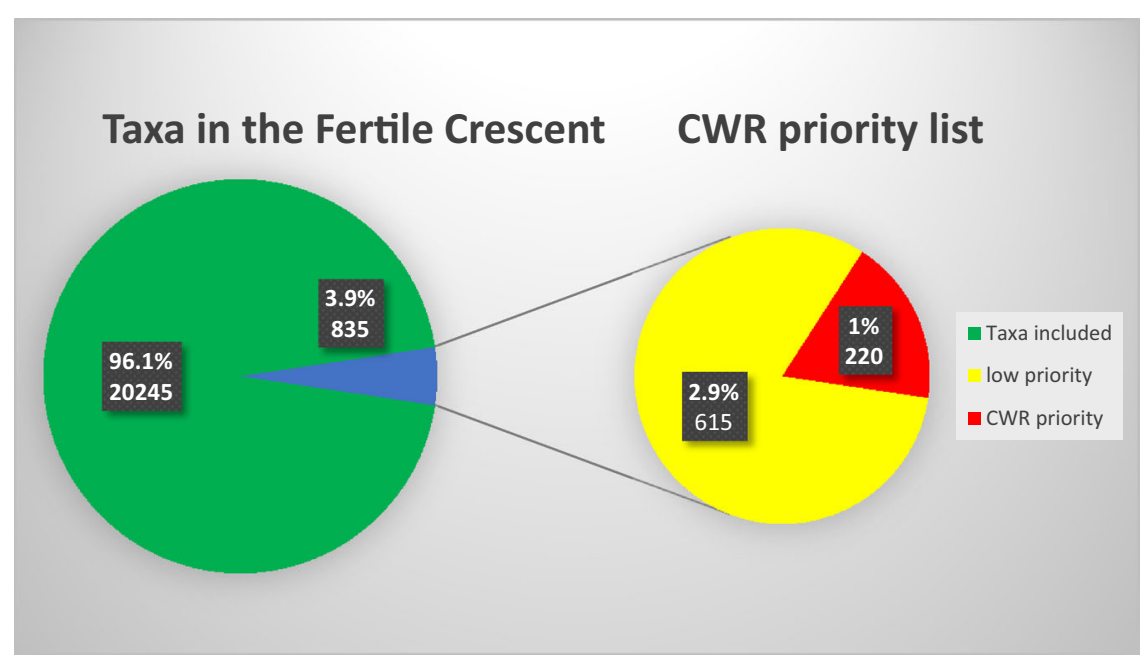


Fig. 3 CWR inventory

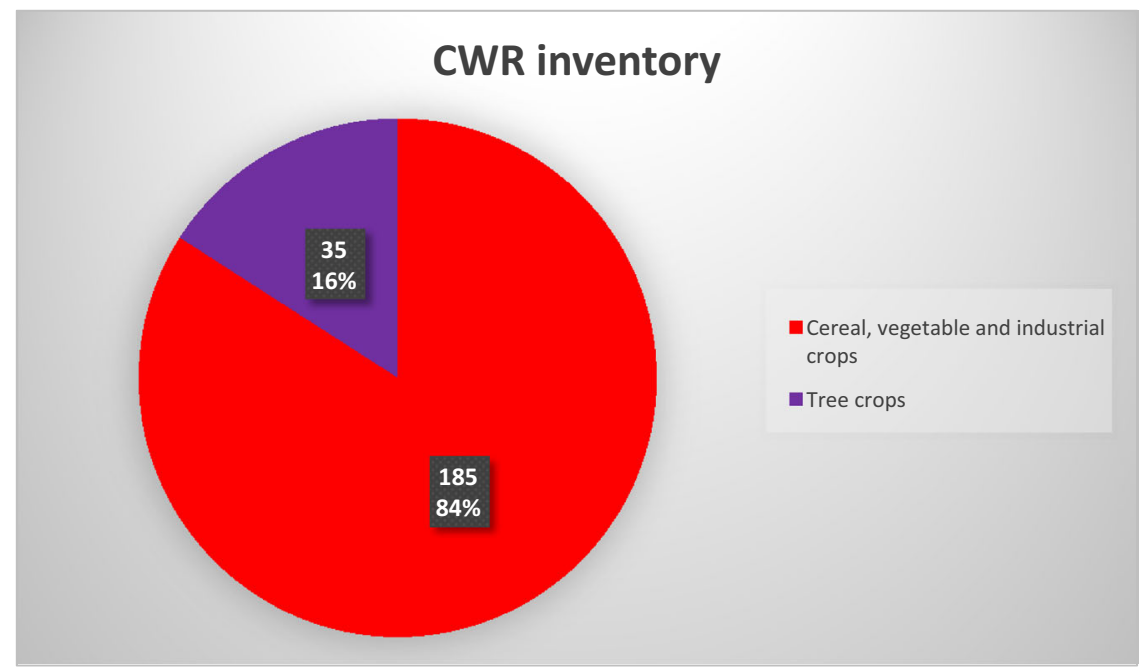

crops which have socio-economic value in the region. The 835 taxa of the Fertile Crescent went through prioritisation processes. The first 220 species based on the twelve prioritisation criteria. The remaining 615 are excluded from the list as they are of lower priority. The CWR priority list contains CWR taxa and relates to cereal, vegetable, and industrial crops and 35 taxa are relates to fruits and trees. Figure 2 shows the organisation of the taxa in the CWR checklist and the CWR inventory.

CWR related to cereals, vegetables and industrial crops accounted for $84 \%$ of the CWR inventory. CWR related to trees accounted for $16 \%$ of the CWR inventory (Fig. 3).

Figure 4 shows the number of taxa per genus included in the priority list.

Figure 5 shows the number of CWR taxa per genus listed in the tree wild relatives' priority list.

Table 3 represents the Number of families, genera, and taxa per general crop use for the CWR included in the inventory.

\section{Discussion}

The purpose of this study is to enhance the conservation of CWR in the Fertile Crescent by creating a CWR checklist for the region, setting prioritisation methods, and creating a CWR inventory. They are acceptable results as the number of
CWR taxa in the checklist is consistent with the number of taxa in the countries of the Fertile Crescent proposed by by Ghazanfar and McDaniel (2015). The approach used in prioritisation which is species-based approach followed a similar approach as Maxted et al. (1997), Magos Brehm et al. (2010), Khoury et al. (2013) and Fielder et al. (2015), where the focus was on species rather than habitat-based prioritisation. The knowledge generated will enable policy makers to implement effective protocols for conservation and sustainable management of such critical plant genetic resources. CWRs play an essential role in the current and upcoming food security strategies; they are a potential source of diversity for domesticated species. CWRs have contributed to improved cultivation by introducing resistant genes against many insect and plant diseases. In addition, they provide improved tolerance to salinity, drought, and extreme temperatures. There is a broad diversity of crops and their wild relatives throughout the Fertile Crescent. For the above-mentioned reasons, this study aims to analyse the diversity of wild relatives of the most significant crops in the Fertile Crescent as a keystone for implementing a regional conservation strategy for such genetic resources. The study will help generate and apply a CWR conservation strategy for the region. Recommendations for further research is to undertake a gap analysis and to generate and apply a CWR conservation strategy for the region. This will 
Fig. 4 The number of taxa per genus included in the priority list
Taxa per genus in CWR priority list

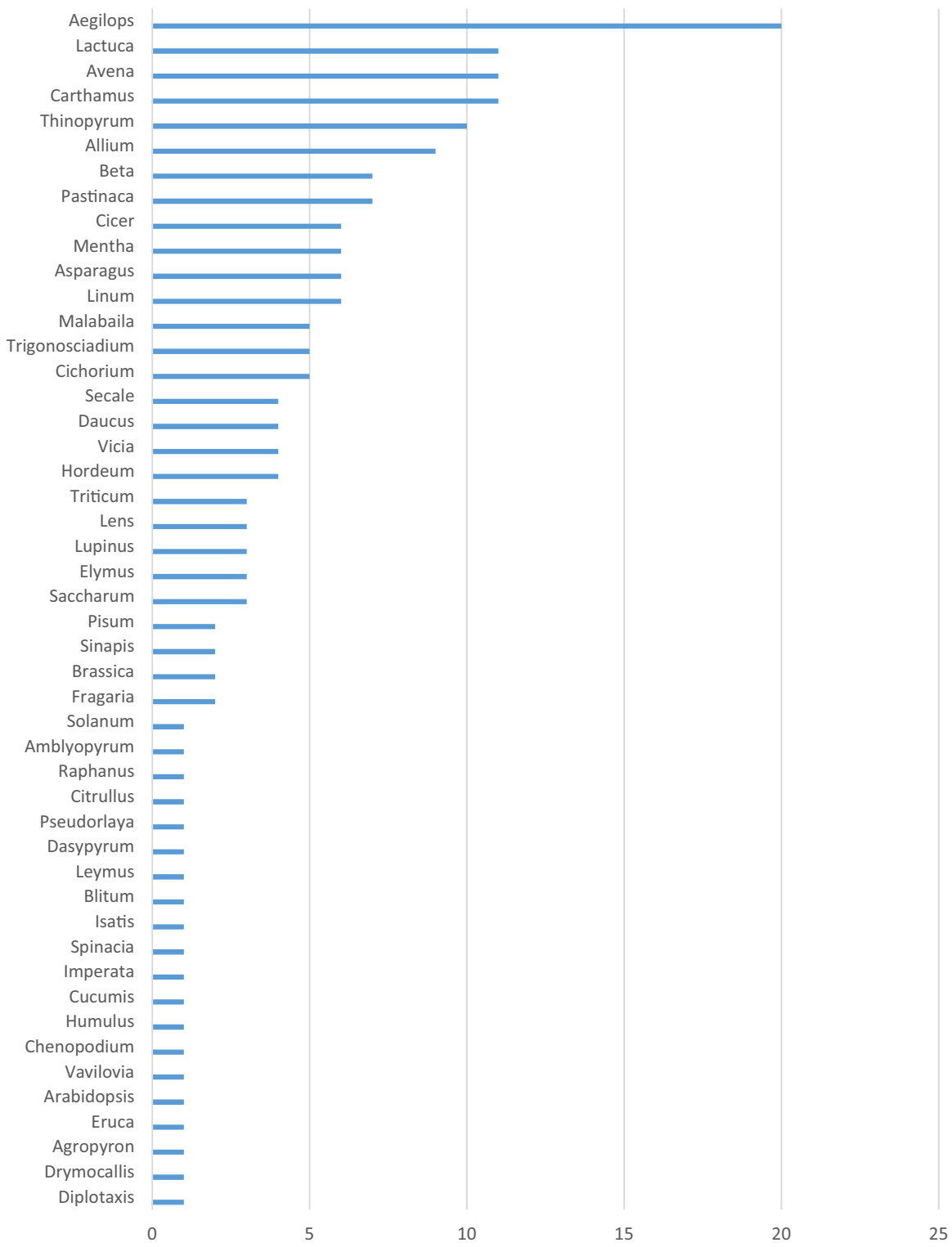

help the world stand against climate change and other threats to agriculture biodiversity and food security. The results and conclusions of this study are important as it is the first time somebody has created a CWR checklist, prioritise and create a
CWR inventory for the Fertile Crescent. These three elements are the first step toward conservation of genetic resources to help our planet stand against climate change and other threats to agriculture biodiversity and food security. 
Fig. 5 Number of CWR taxa per genus listed in the tree wild relatives' priority list

\section{Taxa per genus in tree crop wild relatives priority list}

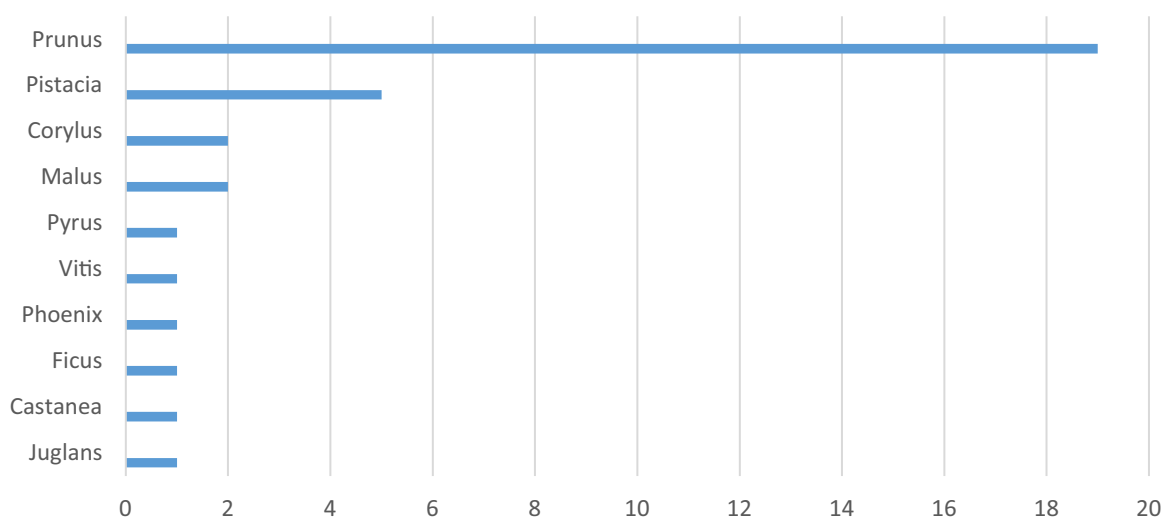

Table 3 Number of families, genera, and taxa per general crop use for the CWR included in the inventory

\begin{tabular}{lcc}
\hline General crop use & \multicolumn{2}{l}{ Priority list } \\
\cline { 2 - 3 } & Families & Genera \\
\hline Cereal & 2 & 6 \\
Forage & 1 & 3 \\
Fruit and nuts & 8 & 18 \\
Industrial & 2 & 3 \\
Legume & 1 & 5 \\
Herb and spice & 2 & 2 \\
Oilseed & 2 & 2 \\
Vegetable & 8 & 15 \\
Total & 26 & 54 \\
\hline
\end{tabular}

\section{Conclusion}

We present the first inventory of 220 priority CWR for the Fertile Crescent. The inventory helps to improve the in situ and ex situ conservation and the genetic diversity of CWR. Both the inventory and the methodology applied in prioritisation are applicable and can be used in setting national, regional, and global conservation strategies. The recommendations will help the Fertile Crescent meet its targets in conserving CWR diversity as well as making sure that CWR genetic resources are preserved to prevent and tackle global food insecurity.

Acknowledgements Funding was provided by the CARA foundation, Said foundation, Russell IPM, and the University of
Birmingham. We would like to thanks all their teams. The funding source has no involvement in conducting the research or preparation of the article.

\section{Compliance with ethical standards}

Conflict of interest The authors declare that they have no conflict of interest.

Open Access This article is distributed under the terms of the Creative Commons Attribution 4.0 International License (http:// creativecommons.org/licenses/by/4.0/), which permits unrestricted use, distribution, and reproduction in any medium, provided you give appropriate credit to the original author(s) and the source, provide a link to the Creative Commons license, and indicate if changes were made.

\section{References}

Appels R, Lagudah ES (1990) Manipulation of chromosomal segments from wild wheat for the improvement of bread wheat. Aust J Plant Physiol 17:253-266

Araus JL, Slafer GA, Royo C, Serret MD (2008) Breeding for yield potential and stress adaptation in cereals. Crit Rev Plant Sci 27:377-412

Barazani O, Perevolotsky A, Hadas R (2008) A problem of the rich: prioritizing local plant genetic resources for ex situ conservation in Israel'. Biol Conserv 141:596-600

Castaneda-Alvarez NP, Khoury CK, Achicanoy HA, Bernau V, Dempewolf H, Eastwood RJ, Gurarino L, Harker RH, Javis A, Maxted N, Mueller JV, Ramirez-Villegas J, Sosa CC, Struik PC, Vincent H, Toll J (2016) Global conservation priorities for crop wild relatives. Nat Plants 2:16022. doi:10.1038/NPLANTS.2016.22

Derneg D (2010) Ecosystem profile: Mediterranean basin biodiversity hotspot. CEPF-critical ecosystem partnership fund. http://www.cepf.net/Documents/Mediterranean_ EP_FINAL.pdf 
El-Beltagy A (2006) Central and West Asia and North Africa: challenges and opportunities. ICARDA, Aleppo

FAOSTAT (2016) Economic value of food and agricultural commodities in the Fertile Crescent. http://faostat.fao.org/ site/339/default.aspx. Accessed 15 Feb 2016

Fielder H, Brotherton P, Hosking J, Hopkins JJ, Ford-Lloyd B, Maxted N (2015) Enhancing the conservation of crop wild relatives in England. PLoS ONE 10(6):e0130804. doi:10. 1371/journal.pone.0130804

Ford-Lloyd B, Kell SP, Maxted N (2008) Establishing conservation priorities for crop wild relatives. In: Maxted N, Ford-Lloyd BV, Kell SP, Iriondo JM, Dullo E, Turok J (eds) Crop wild relative conservation and use. CAB International, Wallingford, pp 110-119

Ghazanfar SA, McDaniel T (2015) Floras of the middle east: a quantitative analysis and biogeography of the flora of Iraq. Edinb J Bot 73(1):1-24

Guner A, Aslan S, Ekim T, Vural M, Babaç MT (2012) Türkiye Bitkileri listesi. Nezahat gökyi $\breve{g}$ it botanik bahçesi ve flora arastirmalari derne $\breve{g}$ i yayini, Istanbul

Hanelt $\mathrm{P}$, Institut für Pflanzengenetik und Kulturpflanzenforschung Gatersleben (eds) (2001) Mansfeld's encyclopaedia of agricultural and horticultural crops. Springer, Berlin

Heywood VH (2003) Mediterranean plant collections: needs and options. Setting the scene: what we have inherited. Bocconea 16(1):283-287

Keisa A, Maxted N, Ford-Lloyd BV (2008) The assessment of biodiversity loss over time: wild legumes in Syria'. Genet Resour Crop Evol 55(313):603-612

Kew (2016) The state of the world's plants report-2016. Royal Botanic Gardens, Kew, London

Khoury CK, Greene S, Wiersema J, Maxted N, Jarvis A, Struik PC (2013) An inventory of crop wild relatives of the United States. Crop Sci 53(4):1496-1508

Magos Brehm MJ, Maxted N, Ford-Lloyd VB, Martins-Loucao AM (2010) New approaches for establishing conservation priorities for socio-economically important plant species. Biodivers Conserv 19(9):2715-2740

Maxted N, Kell SP (2009) Establishment of a global network for the in situ conservation of crop wild relatives: status and needs. http://www.fao.org/docrep/013/i1500e/i1500e18a. pdf. Accessed July 2016

Maxted N, Hawkes JG, Guarino L, Sawkins M (1997) The selection of taxa for plant genetic conservation. Genet Resour Crop Evol 44(4):337-348

Maxted N, Ford-Lloyd BV, Jury S, Kell S, Scholten M (2006) Towards a definition of a crop wild relative. Biodivers Conserv 15(8):2673. http://www.springerlink.com/index/ 10.1007/s10531-351005-5409-6. Accessed 02 Nov 2016

Maxted N, Scholten M, Codd R, Ford-Lloyd B (2007) Creation and use of a national inventory of crop wild relatives. Biol Conserv 140:142-159

Mitteau M, Soupizet F (2000) Preparation of a preliminary list of priority target species for in situ conservation in Europe. In: Laliberté B, Maggioni L, Maxted N, Negri V (eds) ECP/ GR in-situ and on-farm conservation network report of a task force on wild species conservation in genetic reserves and a task force on on-farm conservation and management joint meeting, 18-20 May 2000, Isola Polvese Italy Isola Polvese, Italy. IPGRI Rome Italy. IPGRI, Rome, pp 32-42
Mouterde P (1970) Nouvelle flore du Liban et de la Syrie. Beyrouth, Editions de l'Impr. catholique, Beirut

Nevo E, Chen GX (2010) Drought and salt tolerances in wild relatives for wheat and barley improvement. Plant Cell Environ 33:670-685

Post GE (1933) Flora of Syria, Palestine and Sinai: a handbook of the flowering plants and ferns, native and naturalized from the Taurus to Ras Muhammad and from the Mediterranean Sea to the Syrian desert, 2nd edn. extensively revised and enlarged. American Press, Beirut

Schippmann U, Cunningham AB, et Leaman DJ (2002) Impact of cultivation of medicinal plants on biodiversity: global trends and issues.In: FAO (ed) Biodiversity and the ecosystem approach in agri-culture, forestry and fisheries, inter-departmental working group on biological diversity for food and agriculture. FAO, Rome, Italy. In vitro efficacy of selected medicinal plants from Cholistan desert, Pakistan, against gastrointestinal helminths of sheep and goats, pp 143-167. https://www.researchgate.net/publication/ 308985020_In_vitro_efficacy_of_selected_medicinal_plants_ from_Cholistan_desert_Pakistan_against_gastrointestinal_ helminths_of_sheep_and_goats. Accessed 1 Nov 2016

Schultze-Motel J (1966) Verzeichnis forstlich kultivierter Pflanzenarten [Enumeration of cultivated forest plant species]. Kulturpflanze Beiheft 4:486

Taifour H, El-Ohlah A (2014) Jordan plant red list, vol I. Royal Botanic Garden, Kew

Taifour H, El-Oqlah A (2017) The plants of Jordan: an annotated checklist. Royal Botanic Gardens, Kew, London

Trigo RM, Gouveia CM, Barriopedro D (2010) The intense 2007-2009 drought in the Fertile Crescent: impacts and associated atmospheric circulation. Agric Meteorol 150(9):1245-1257

UN (United Nations, Department of Economic and Social Affairs, Population Division) (2017) World population prospects: the 2017 revision, key findings and advance tables. Working paper no. ESA/P/WP/248

Vavilov NI (1926) Studies in the origin of cultivated plants. Institute of Applied Botany and Plant Breeding, Leningrad

Vincent H, Wiersema J, Dobbie S, Kell SP, Fielder H, Castenada N, Eastwood R, Guarino L, et Maxted N (2012) Global checklist of priority crop wild relatives [online]. www. cwrdiversity.org

Vincent H, Wiersema J, Dobbie S, Kell SP, Fielder H, Castãneda Alvarez NP, Guarino L, Eastwood R, León B, Maxted N (2013) A prioritised crop wild relative inventory as a first step to help underpin global food security. Biol Conserv 167:265-275

Willcox G (2012) The beginnings of cereal cultivation and domestication in Southwest Asia. In: Potts D (ed) A companion to the archaeology of the ancient near east. Blackwell, Chicester, pp 163-180

Zeder MA (2011) The origins of agriculture in the near east. Curr Anthropol 52(S4):S221-S235

Zeven AC, De Wet JMJ (1982) Dictionary of cultivated plants and their regions of diversity: excluding most ornamentals, forest trees and lower plants. CAPD, Wageningen

Zohary M (1966-1986) Flora palaestina, vol 1-4. Israel academy of sciences and humanities Goldberg's press, Jerusalem 